\title{
Orthomyxo-, paramyxo- and flavivirus infections in wild waterfowl in Finland
}

\author{
Erika Lindh*1, Anita Huovilainen², Osmo Rätti ${ }^{3}$, Christine Ek-Kommonen², \\ Tarja Sironen ${ }^{1}$, Eili Huhtamo ${ }^{1}$, Hannu Pöysä ${ }^{5}$, Antti Vaheri1,6 and \\ Olli Vapalahti ${ }^{1,4,6}$
}

Address: ${ }^{1}$ Department of Virology, Haartman Institute, Faculty of Medicine, P.O. Box 21, FI-00014 University of Helsinki, Finland, ${ }^{2}$ Finnish Food Safety Authority Evira, Department of Animal Diseases and Food Safety Research, Virology Unit, Mustialankatu 3, FI-00790 Helsinki, Finland, ${ }^{3}$ Arctic Centre, University of Lapland, P.O. Box 122, FI-96101 Rovaniemi, Finland, ${ }^{4}$ Division of Microbiology and Epidemiology, Department of Basic Veterinary Sciences, Faculty of Veterinary Medicine, P.O. Box 66, FI-00014 University of Helsinki, Finland, ${ }^{5}$ Finnish Game and Fisheries Research Institute, Joensuu Game and Fisheries Research, Yliopistonkatu 6, FI-80100 Joensuu, Finland and ${ }^{6}$ Department of Virology, HUSLAB, Hospital District of Helsinki and Uusimaa, P.O. Box 400, FI-00029 HUS, Helsinki, Finland

Email: Erika Lindh* - erika.lindh@helsinki.fi; Anita Huovilainen - anita.huovilainen@evira.fi; Osmo Rätti - osmo.ratti@ulapland.fi; Christine Ek-Kommonen - christine.ek-kommonen@evira.fi; Tarja Sironen - tarja.sironen@ helsinki.fi; Eili Huhtamo - eili.huhtamo@helsinki.fi; Hannu Pöysä - hannu.poysa@rktl.fi; Antti Vaheri - antti.vaheri@helsinki.fi; Olli Vapalahti - olli.vapalahti@helsinki.fi

* Corresponding author

Published: 28 February 2008

Virology Journal 2008, 5:35 doi:10.1186/1743-422X-5-35

This article is available from: http://www.virologyj.com/content/5/I/35

(C) 2008 Lindh et al; licensee BioMed Central Ltd.

This is an Open Access article distributed under the terms of the Creative Commons Attribution License (http://creativecommons.org/licenses/by/2.0), which permits unrestricted use, distribution, and reproduction in any medium, provided the original work is properly cited.

\begin{abstract}
Background: Screening wild birds for viral pathogens has become increasingly important. We tested a screening approach based on blood and cloacal and tracheal swabs collected by hunters to study the prevalence of influenza A, paramyxo-, flavi-, and alphaviruses in Finnish wild waterfowl, which has been previously unknown. We studied 310 blood samples and II 5 mixed tracheal and cloacal swabs collected from hunted waterfowl in 2006. Samples were screened by RT-PCR and serologically by hemagglutination inhibition $(\mathrm{HI})$ test or enzyme-linked immunosorbent assay (ELISA) for influenza A (FLUAV), type I avian paramyxo-(APMV-I), Sindbis (SINV), West Nile (WNV) and tick-borne encephalitis (TBEV) virus infections.

Results: FLUAV RNA was found in 13 tracheal/cloacal swabs and seven strains were isolated. Five blood samples were antibody positive. Six APMV-I RNA-positive samples were found from which four strains were isolated, while two blood samples were antibody positive. None of the birds were positive for flavivirus RNA but three birds had flavivirus antibodies by $\mathrm{HI}$ test. No antibodies to SINV were detected.

Conclusion: We conclude that circulation of both influenza $A$ virus and avian paramyxovirus-I in Finnish wild waterfowl was documented. The FLUAV and APMV-I prevalences in wild waterfowl were $11.3 \%$ and $5.2 \%$ respectively, by this study. The subtype H3N8 was the only detected FLUAV subtype while APMV-I strains clustered into two distinct lineages. Notably, antibodies to a likely mosquito-borne flavivirus were detected in three samples. The screening approach based on hunted waterfowl seemed reliable for monitoring FLUAV and APMV by RT-PCR from cloacal or tracheal samples, but antibody testing in this format seemed to be of low sensitivity.
\end{abstract}




\section{Background}

Influenza A virus (FLUAV) is a member of the family Orthomyxoviridae, naturally hosted by wild waterfowl. All subtypes, composed by different combinations of the 16 hemagglutinin (HA) types and 9 neuraminidase (NA) types, have been isolated from birds but lineages of certain viruses are occasionally established in non-avian hosts including humans $[1,2]$. Most strains found in wild waterfowl are of the low-pathogenic avian influenza (LPAI) phenotype. Highly pathogenic (HPAI) phenotypes of $\mathrm{H} 5$ and $\mathrm{H} 7$ subtypes have increasingly caused disease outbreaks in poultry and the H5N1 type initially isolated in China has spread throughout Asia and into Europe and Africa infecting both poultry and wild birds [3]. The emergence of HPAI and the ecology of FLUAV in wild waterfowl have been reviewed elsewhere [4].

Occurence of influenza A viruses in wild birds has been monitored since 2003 in the EU including Finland. Although high prevalences of FLUAV in wild waterfowl have been reported from other Northern European countries $[5,6]$ the previous Finnish findings of FLUAV infected birds are limited to a few viruses of the H13N6 subtype isolated from herring gulls in 2005 (Jonsson et al., manuscript in preparation) and to the isolation of an untyped FLUAV from a mallard in 1979 [7].

Newcastle disease (ND) in poultry is caused by type 1 of the nine species (designated avian paramyxovirus 1-9) in the genus Avulavirus, a member of the family Paramyxoviridae [8]. Avian paramyxovirus-1 (APMV-1) infects a wide range of bird species of different orders causing disease of varying severity. The strains are classified according to the pathogenicity in chickens and the deduced amino acid sequence of the cleavage site of the fusion protein into lentogenic (mildly virulent), mesogenic (intermediate virulence) and velogenic (highly virulent) strains [9]. Similar to FLUAV, velogenic strains of APMV-1 are suspected to arise from lentogenic strains, derived from wild birds [10]. Based on genetic and antigenic analyses of isolates obtained during several decades, the existence of at least eight different genotypes (I-VIII) has been shown [11-15]. Spatio-temporal and host-species associations are often seen inside these groups. Phylogenetic analysis based on the F-gene separates APMV-1 strains into class 1 and 2 clades, and the later into two sublineages which comprise the previously defined genotypes [16,17]. Lentogenic viruses of class 2 , genotype 1 , are naturally hosted by wild waterfowl and have an ecology resembling that of influenza A $[18,19]$. Class 1 viruses have also been recovered worldwide, mainly from wild waterfowl, and are with few exceptions of low-pathogenicity $[12,19]$.

ND is regarded as one of the most important pathogens in the poultry industry where it has a great economic impact.
Four ND outbreaks have occurred in Finland [20-22], the latest in 2004 when ND affected a flock of 12000 turkeys (Ek-Kommonen, unpublished results), which were consequently destroyed. The need for vaccination of poultry in Finland was evaluated and Newcastle disease is currently controlled without vaccines.

The role of waterfowl in some of the endemic zoonotic virus infections has not been settled. In order to expand the knowledge of their prevalences in the Finnish waterfowl population, flavi-and alphaviruses were included in the study.

Sindbis virus (SINV) is a mosquito-borne virus of the genus Alphavirus in the family Togaviridae. It is known to cause epidemics in humans in Northern Europe characterized by fever, rash and polyarthritis [23]. The outbreaks appear to occur at 7-year intervals; the latest being in 2002 with 600 serologically verified human cases in Finland [24]. A high seroprevalence in resident birds can be seen one year after an outbreak [25].

The family Flaviviridae consists of about 70 viruses, most of which are arthropod-borne zoonotic agents. They infect a wide variety of vertebrates including mammals, avians and amphibians. Tick-borne encephalitis virus (TBEV) is the most important flavivirus in Europe, where it is endemic in several countries and has a significant impact on public health. The virus is maintained in ticks and wild vertebrates and transmission to humans occurs generally via tick bites [26]. West Nile virus is a mosquito-borne flavivirus endemic in Europe. Until recently, it was considered an Old World virus infecting predominantly humans and equines. Outbreaks of WN fever have been reported e.g. in humans in Romania 1996 [27] and in horses in France 2000 [28]. Since the outbreak in New York started in 1999, the virus has dispersed throughout North and Central America and is now endemic in most US states and Canadian provinces [29]. Disease in WNV-infected birds varies from symptomless to death, corvids (family Corvidae) being the most sensitive to lethal infections [30]. Wild bird infections by WNV, Usutu virus and SINV have been documented and birds are believed to be able to transmit these viruses geographically over long distances [31]. Migratory birds have also been shown to carry e.g. TBEV-infected ticks [32].

In order to address this need of wild bird surveillance, we chose to use an approach where hunters were recruited for blood and swab sample collection. In total 310 blood samples and 115 tracheal and cloacal swab samples were collected and studied in year 2006. Our main interest was to study the distribution of FLUAV and APMV-1 infections in our wild waterfowl populations. As SINV and TBEV are established zoonotic agents in Finland, the understanding 
of their ecology and possible links to wild waterfowl was also of special interest.

In this study, the circulation of both influenza A virus and APMV-1 in Finnish wild waterfowl was documented and isolated FLUAV and APMV-1 strains were genetically and phylogeneticaly characterized.

\section{Results}

\section{Antibody and virus detection}

Antibodies to influenza A were detected by a commercial competitive ELISA (FLUACA). Out of 310 blood specimens, three samples, all from mallards (Anas platyrhynchos), were positive (competitive percentages $<45$ ). Two samples, one from a mallard and one from a common teal (Anas crecca) were regarded as borderline (competitive percentages 45-50). Examination of the 115 combined tracheal and cloacal swab samples showed that 13 samples were positive when studied by the influenza A Mgene specific real time RT-PCR (cycle threshold -values (Ct) 21.15-38.86); none of the samples were positive by H5-or H7-specific real-time RT-PCR. After inoculation of RT-PCR-positive specimen into embryonated eggs, 7 influenza virus isolates were successfully obtained. In only one of the samples (A/mallard/Finland/12072/06) could both antibodies (competitive percentage 48.8) and viral RNA (Ct-value 32.2) be detected (Table 1).

In the screening for APMV infections, two samples, one from a common teal and one from a mallard, had titers of 1:40 in the hemagglutination inhibition (HI) test with APMV/Ulster antigen. Of the swab specimens, 6 were RTPCR positive and from 4 of them, APMV-1 was successfully isolated in egg culture. Three of the isolates derived from common teals and one from a common pochard (Aythya ferina). None of the birds were positive in both RT-PCR and HI (Table 1).

When tested for antibodies to SINV by HI, none of the blood samples were found positive. Samples were not studied for SINV infections by PCR. However, three samples, all from mallards, reacted positively with WNV antigens in the HI test. Two of them had low titers of $>1: 20$ while one reached a titer of 1:6120. Consequently, the sera were tested in parallel with TBEV antigen: the TBEV antibody titer was lower for each sample, with titers $<1: 20,<1: 20$ and 1:1280, respectively. None of the 100 studied swab samples were positive for flavivirus RNA by

Table I: Influenza A and APMV-I positive samples.

\begin{tabular}{|c|c|c|c|c|c|c|c|c|}
\hline \multirow[b]{2}{*}{ Sample number } & \multirow[b]{2}{*}{ Scientific name } & \multirow[b]{2}{*}{ Species } & \multicolumn{3}{|c|}{ INFLUENZA A } & \multicolumn{3}{|c|}{ APMV-I } \\
\hline & & & RT-PCR (Ct) & Isolation & Serology & RT-PCR & Isolation & Serology \\
\hline 199 & Anas platyrhynchos & Mallard & nd & nd & + & nd & nd & - \\
\hline 301 & Anas platyrhynchos & Mallard & nd & nd & + & nd & nd & - \\
\hline 12054 & Anas crecca & Common teal & - & - & - & + & - & - \\
\hline 12072 & Anas platyrhynchos & Mallard & $+(32.6)$ & $\mathrm{H} 3 \mathrm{~N} 8$ & + & - & - & - \\
\hline 12074 & Anas crecca & Common teal & $+(34.3)$ & H3N8 & - & + & - & - \\
\hline 12075 & Anas platyrhynchos & Mallard & - & - & + & - & - & - \\
\hline 12104 & Anas crecca & Common teal & - & - & - & + & APMV-I & - \\
\hline 12110 & Anas platyrhynchos & Mallard & $+(37.5)$ & H3N8 & - & - & - & - \\
\hline 12115 & Anas acuta & Northern pintail & $+(38.4)$ & - & - & - & - & - \\
\hline 12117 & Anser fabalis & Bean goose & $+(38.1)$ & - & - & - & - & - \\
\hline 12119 & Anas crecca & Common teal & $+(38.0)$ & - & - & + & APMV-I & - \\
\hline 12132 & Anas platyrhynchos & Mallard & $+(33.6)$ & H3N8 & - & - & - & - \\
\hline 12133 & Anas platyrhynchos & Mallard & $+(38.8)$ & H3N8 & - & - & - & - \\
\hline 12136 & Anas crecca & Common teal & - & - & - & + & APMV-I & - \\
\hline 13153 & Anas crecca & Common teal & - & - & + & - & - & + \\
\hline 13164 & Anas platyrhynchos & Mallard & $+(38.1)$ & - & - & - & - & + \\
\hline $1317 \mid$ & Anas platyrhynchos & Mallard & $+(23.8)$ & H3N8 & - & - & - & - \\
\hline 13176 & Anas platyrhynchos & Mallard & $+(38.7)$ & - & - & - & - & - \\
\hline 13183 & Anas platyrhynchos & Mallard & $+(2 I .1)$ & H3N8 & - & - & - & - \\
\hline 13185 & Anas platyrhynchos & Mallard & $+(38.1)$ & - & - & - & - & - \\
\hline 13193 & Aythya ferina & Common pochard & - & - & - & + & APMV-I & - \\
\hline Positives/total & & & $13 / 115$ & $7 / 115$ & $5 / 310$ & $6 / 115$ & $4 / 115$ & $2 / 310$ \\
\hline Percentage positives & & & $11.3 \%$ & $6.1 \%$ & $1.6 \%$ & $5.2 \%$ & $3.4 \%$ & $0.6 \%$ \\
\hline
\end{tabular}

Summary of influenza A virus and avian paramyxovirus-I findings in the waterfowl samples. Positive samples are presented according to the detection method. nd = not done, sample not available. 
the hemi-nested RT-PCR using conserved primers covering most mosquito-borne flaviviruses and TBEV [33]. Positive WNV-RNA controls produced bands of the expected size.

\section{Subtyping and genetic characterization}

By serological analysis, in HI test with subtype-specific antisera, the influenza strains proved to be of the $\mathrm{H} 3$ subtype. Genetic analysis of the HA and NA gene sequences verified them to be of the H3N8 subtype. Nucleotide sequence alignments with the inner segment of the HA (nt 482-1166) and NA (nt 605-973) genes of the seven isolates showed that sequence identities between the isolates and the characterized strain A/mallard/Finland/12072/06 ranged from $97.2 \%$ to $99.7 \%$. Sequence comparison revealed a close similarity (by BLAST) of the $\mathrm{H} 3$ gene to strains isolated from ducks in Nanchang, China [GenBank: CY006015] (97\% identity) and Denmark [GenBank: AY531031] (97\% identity) (Figure 1, Table 2). The closest similarity of the N8 gene was likewise to the Dan- ish strain [GenBank: AY531032] (97\% identity) and a Norwegian strain [GenBank: AJ841294] (97\% identity) (Figure 2, Table 3). Both genes of $\mathrm{A} /$ mallard/Finland/ $12072 / 06$ clustered phylogeneticaly together with mainly Eurasian strains.

Sequences of the F genes of the APMV-1 isolates revealed that the isolates were of two different lineages (Figure 3, Table 4): three isolates had a high similarity (98-99\% identity by BLAST] to strain FIN-97 [GenBank: AY034801], a previous Finnish isolate, and to the North American strain US/101250-2/01 [GenBank: AY626268], of class 1 . One isolate and one sample only positive by RTPCR were most similar to Far Eastern isolates [GenBank: AY965079, AY972101] (99\% identity) and had 96\% similarity to strain Ulster/67 [GenBank: AY562991] representing class 2, genotype I.

The cleavage site of the fusion (F) protein has been generally used as an indicator for pathogenicity. Velogenic

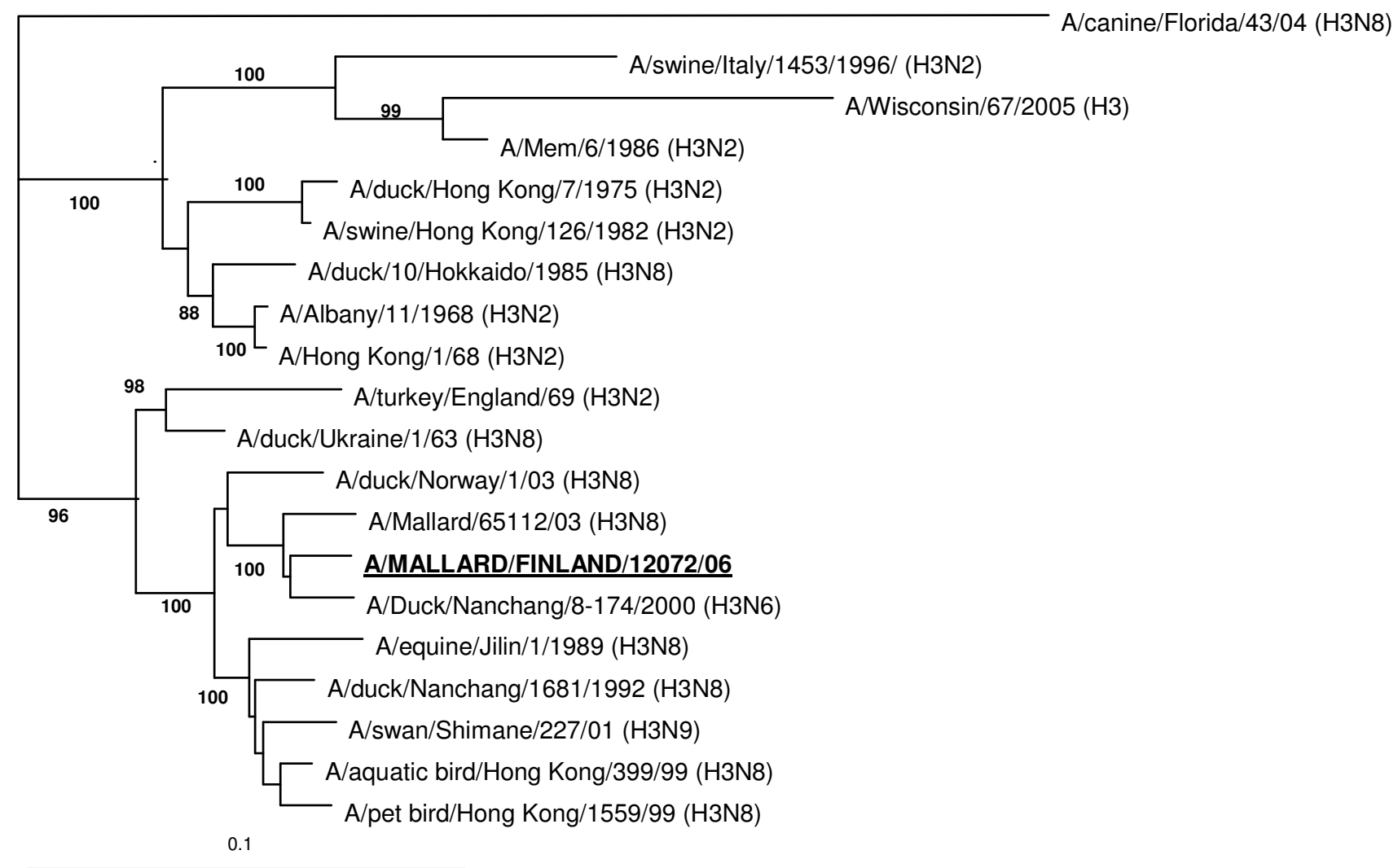

\section{Figure I}

Phylogenetic analysis of the $\mathbf{H 3}$ gene of A/mallard/Finland/I 2072/06. Phylogenetic analysis of the $\mathrm{H3}$ gene (684 nt). The tree was generated by neighbor-joining algorithm using A/canine/Florida/43/04 (H3) as outgroup. Alignments were bootstrapped 100 times. The numbers indicate confidence of analysis (bootstrap support $>70 \%$ shown). Details and GenBank accession numbers to the strains are indicated in Table 2. 


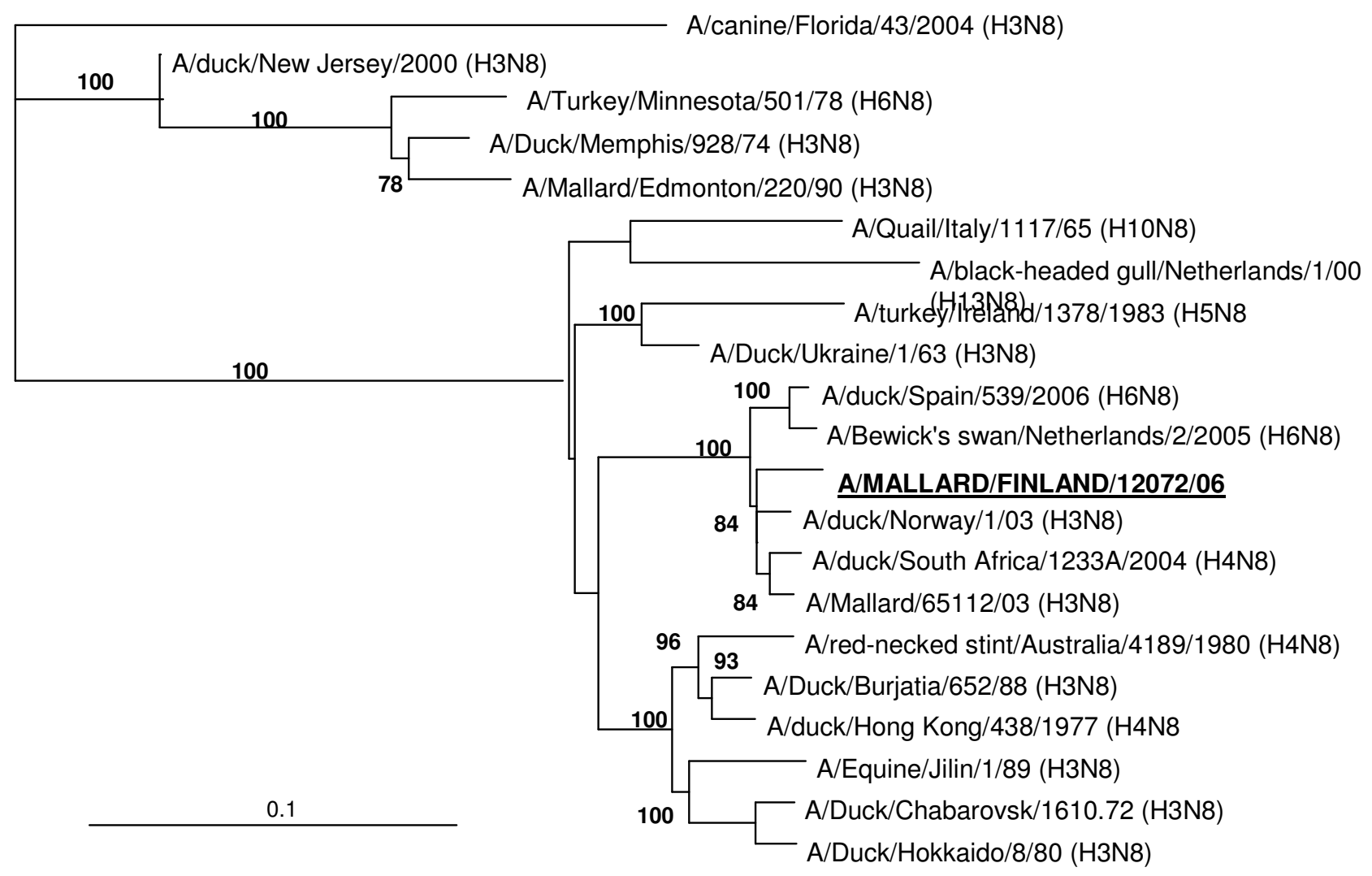

\section{Figure 2}

Phylogenetic analysis of the N8 gene of A/mallard/Finland/I 2072/06. Phylogenetic analysis of the N8 gene (368 nt). The tree was generated by neighbor-joining algorithm using A/canine/Florida/43/04 (N8) as outgroup. Alignments are bootstrapped 100 times. The numbers indicate confidence of analysis (bootstrap support $>70 \%$ shown). Details and GenBank accession numbers to the strains are indicated in Table 3.

strains possess at least two basic amino acids immediately surrounding glutamine 114 while lentogenic strains lack this domain $[34,35]$. Our strains had either the cleavage site sequence SGGERQERLVG or SGGGKQGRLIG, both typically found in lentogenic strains (Table 5).

The sequences obtained from the isolates described in this study have been submitted to GenBank with the accession numbers listed in Tables 2, 3, 4 .

\section{Discussion}

The circulation of influenza A viruses in the Finnish waterfowl population in fall 2006 was shown in this study; no viruses of the potentially highly pathogenic $\mathrm{H} 5$ or $\mathrm{H} 7 \mathrm{sub}-$ types could be detected. According to the M-gene realtime RT-PCR, the prevalence of influenza A viruses was $11.3 \%(\mathrm{n}=115)$ in all analysed birds, $16.3 \%(\mathrm{n}=55)$ in all analysed mallards (Anas platyrhynchos) and 5.4\% ( $\mathrm{n}=$ 37 ) in all analysed teals (Anas crecca). These values corre- spond well with previous studies where extensive studies on wild waterfowl in Sweden have shown a $14.5 \%$ prevalence of FLUAV during fall, when the prevalence appears to be highest [36]. Although influenza A viruses replicate mainly in the intestinal tract and are shed with feces to wading waters [37], recently it has been suggested that at least some of the HPAI strains are preferentially recovered from tracheal specimen. Whether the viral RNA obtained in our study was recovered from tracheal or from cloacal specimen remains unknown as these were pooled together. It is also noteworthy that the viral load estimated by real-time RT-PCR varied considerably in the 7/13 FLUAV isolation positive samples: two samples were strongly positive (Ct 21-24) while five samples were much weaker positives $(\mathrm{Ct}>32$, two of these $\mathrm{Ct}>37$ ). The prevalence of infection of FLUAV when studied by the presence of specific antibodies by a commercial competitive ELISA was only $1.6 \%(n=310)$. Screening of antibod- 
Table 2: GenBank accession numbers for strains used in phylogenetic analysis of influenza A H3 gene.

\begin{tabular}{|c|c|c|c|}
\hline GenBank & Designation & Country of origin & Host \\
\hline AB289341 & A/swan/Shimane/227/0I (H3N9) & Japan & Swan \\
\hline$\underline{A F 348177}$ & A/Hong Kong/I/68 (H3N2) & Hong Kong & Human \\
\hline A) 427297 & A/aquatic bird/Hong Kong/399/99 (H3N8) & Hong Kong & Aquatic bird \\
\hline A) 427304 & A/pet bird/Hong Kong/I559/99 (H3N8) & Hong Kong & Pet bird \\
\hline A) 841293 & A/duck/Norway/l/03 (H3N8) & Norway & Duck \\
\hline AY531031 & A/Mallard/65II2/03 (H3N8) & Denmark & Mallard \\
\hline AY531037 & A/turkey/England/69 (H3N2) & Great Britain & Turkey \\
\hline CY006016 & A/duck/Nanchang/I68I/I992 (H3N8) & China & Duck \\
\hline$\underline{\mathrm{CY} 006015}$ & A/Duck/Nanchang/8-174/2000 (H3N6) & China & Duck \\
\hline CY006026 & A/duck/Hong Kong/7/I 975 (H3N2) & Hong Kong & Duck \\
\hline$\underline{\text { CY019891 }}$ & A/Albany/II/I968 (H3N2) & Albany & Human \\
\hline$\overline{D Q 124190}$ & A/canine/Florida/43/04 (H3N8) & USA & Canine \\
\hline DQ975261 & A/swine/ltaly/l453/I996 (H3N2) & Italy & Swine \\
\hline EF473424. & A/Wisconsin/67/2005 (H3) & USA & Human \\
\hline MI6743 & A/duck/I0/Hokkaido/I985 (H3N8) & Japan & Duck \\
\hline M19056. & A/swine/Hong Kong// 26/I982 (H3N2) & Hong Kong & Swine \\
\hline $\mathrm{M} 21648$ & $\mathrm{~A} / \mathrm{Mem} / 6 / 1986$ (H3N2) & USA & Human \\
\hline M65018 & A/equine/Jilin/I/I989 (H3N8) & China & Equine \\
\hline$\underline{\mathrm{V} 01087}$ & A/duck/Ukraine/l/63 (H3) & Ukraine & Duck \\
\hline$\overline{\text { EU493448* }}$ & $\mathrm{A} / \mathrm{mallard} /$ Finland//2072/06/H3 & Finland & Mallard \\
\hline
\end{tabular}

* GenBank accession number for sequences from isolates obtained in this study

ies in this format does not seem efficient or sensitive for detection of prevalence of infection.

The subtype diversity of circulating avian influenza viruses in Europe and Asia during the past few years has been extensive, as summarized by Alexander [38], however, only one subtype (H3N8) was recovered in this study. In a Swedish study based on material collected during the years 2002-2004, 11 different HA subtypes and all 9 NA subtypes were found [36]. Out of 129 isolates only 5 were of the H3N8 subtype while in the North American study, described by Krauss et al., viruses of the H3N8 subtype were most commonly found $(22.8 \%$ of isolates from ducks) in the 16-year study [39]. Other recent H3N8 find-

Table 3: GenBank accession numbers for strains used in phylogenetic analysis of influenza A N8 gene.

\begin{tabular}{|c|c|c|c|}
\hline GenBank & Designation & Country of origin & Host \\
\hline$A B 289332$ & A/duck/Hong Kong/438/I 977 (H4N8) & Hong Kong & Duck \\
\hline A]841294 & A/duck/Norway/l/03 (H3N8) & Norway & Duck \\
\hline AM706354 & A/duck/Spain/539/2006 (H6N8) & Spain & Duck \\
\hline AY531032 & A/Mallard/65II $2 / 03$ (H3N8) & Denmark & Mallard \\
\hline AY684900 & A/black-headed gull/Netherlands/I/00 & The Netherlands & Gull \\
\hline AY738457 & A/duck/New Jersey/2000 (H3N8) & USA & Duck \\
\hline CY0I463I & A/red-necked stint/Australia/4/89//980 (H4N8) & Australia & Red-necked stint \\
\hline$\overline{C Y 015091}$ & A/turkey/Ireland/I378/I983 (H5N8) & Ireland & Turkey \\
\hline DQ124I5I & A/canine/Florida/43/2004 (H3N8) & USA & Canine \\
\hline DQ822200 & A/Bewick's swan/Netherlands/2/2005 (H6N8) & The Netherlands & Swan \\
\hline EF04|497 & A/duck/South Africa/I233A/2004 (H4N8) & South Africa & Duck \\
\hline$\underline{\underline{L} 06572}$ & A/Duck/Burjatia/652/88 (H3N8) & Russian Federation & Duck \\
\hline$\underline{L 06573}$ & A/Duck/Chabarovsk/I6I0.72 (H3N8) & Russian Federation & Duck \\
\hline$\underline{\underline{006574}}$ & A/Duck/Hokkaido/8/80 (H3N8) & Japan & Duck \\
\hline$\underline{L 06575}$ & A/Duck/Memphis/928/74 (H3N8) & USA & Duck \\
\hline$\underline{\mathrm{L} 06576}$ & A/Duck/Ukraine/l/63 (H3N8) & Ukraine & Duck \\
\hline$\overline{\mathbf{L 0 6 5 7 9}}$ & A/Equine/jilin/I/89 (H3N8) & China & Equine \\
\hline$\underline{L 06586}$ & A/Mallard/Edmonton/220/90 (H3N8) & USA & Mallard \\
\hline$\underline{\underline{L 06587}}$ & A/Quail/Italy/III $7 / 65$ (HION8) & Italy & Quail \\
\hline$\underline{L 06588}$ & A/Turkey/Minnesota/50I/78 (H6N8) & USA & Turkey \\
\hline EU493449* & A/mallard/Finland/I2072/06/N8 & Finland & Mallard \\
\hline
\end{tabular}

* GenBank accession number for sequences from isolates obtained in this study. 


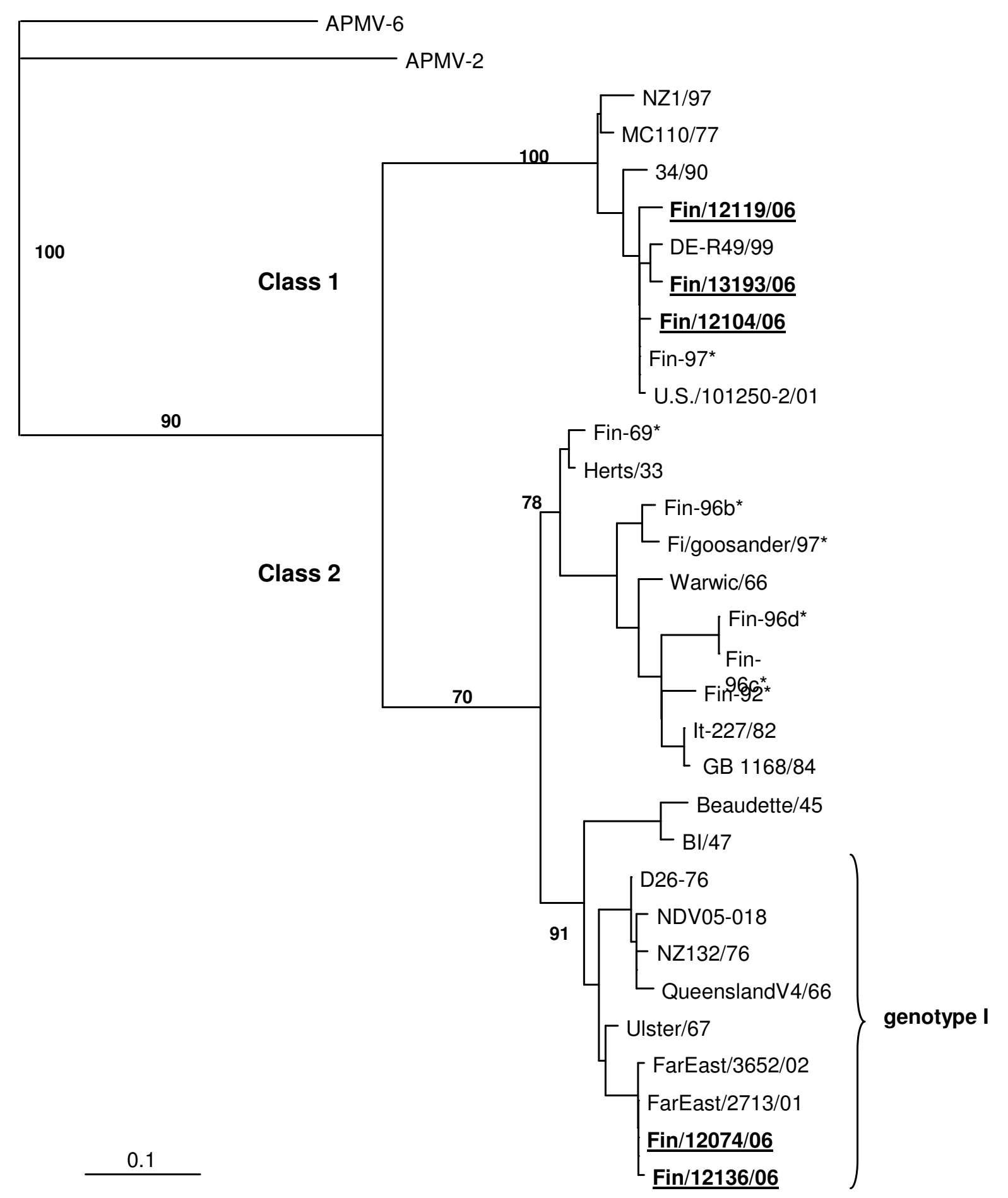

Figure 3

Phylogenetic analysis of APMV-I isolates. Phylogenetic analysis of the F-gene cleavage site (208 nt) of strains isolated in Finland in 2006 . The tree was generated by neighbor-joining algorithm using APMV-2 and APMV-6 as outgroups. Alignments are bootstrapped 500 times. The numbers indicate confidence of analysis. Previous Finnish isolates are marked with *. Details and GenBank accession numbers to the strains are indicated in Table 4. 
Table 4: GenBank accession numbers for strains used in phylogenetic analysis of APMV-I isolates.

\begin{tabular}{|c|c|c|c|}
\hline GenBank & Designation & Country of origin & Host \\
\hline AF003726 & $\mathrm{MCI} / 0 / 77$ & France & Shelduck \\
\hline AF003727 & $34 / 90$ & Ireland & Chicken \\
\hline AF091623 & Fi/goosander//997 & Finland & Goosander \\
\hline AFI09885 & GB II $68 / 84$ & Great Britain & Pigeon \\
\hline AF438366 & $N Z 132 / 76$ & New Zealand & Mallard \\
\hline AF438370 & NZI/97 & New Zealand & Mallard \\
\hline AJ880277 & It-227/82 & Italy & Pigeon \\
\hline AY029299 & APMV-6 & Taiwan & Duck \\
\hline AY034794 & Fin-69 & Finland & Willow grouse \\
\hline$\overline{\text { AY034796 }}$ & Fin-92 & Finland & Pigeon \\
\hline AY034798 & Fin-96b & Finland & Goosander \\
\hline AY034799 & Fin-96c & Finland & Pigeon \\
\hline AY034800 & Fin-96d & Finland & Pigeon \\
\hline AY03480I & Fin-97 & Finland & Mallard \\
\hline AY74I404 & Herts/33 & Great Britain & Chicken \\
\hline AY562991 & Ulster/67 & Ireland & Chicken \\
\hline AY626268 & U.S./I0I250-2/200I & USA & Chicken \\
\hline AY965079 & FarEast/27I3/200I & Russian Federation & Duck \\
\hline AY972101 & FarEast/3652/2002 & Russian Federation & Duck \\
\hline DI3977 & APMV-2, Yucopa & USA & Chicken \\
\hline DQ097393 & DE-R49/99 & Germany & Duck \\
\hline DQ439875 & NDV05-018 & China & Chicken \\
\hline M24692 & D26-76 & Japan & Chicken \\
\hline M24693 & QueenslandV4/66 & Australia & Chicken \\
\hline M24695 & $\mathrm{Bl} / 47$ & USA & Chicken \\
\hline$\underline{\times 04719}$ & Beaudette/45 & USA & Chicken \\
\hline$\overline{Z 12111}$ & Warwic/66 & Great Britain & Chicken \\
\hline EU493450* & APMV-I/teal/Finland/I2074/06 & Finland & Teal \\
\hline$\overline{\text { EU49345I* }}$ & APMV-I/teal/Finland/I2104/06 & Finland & Teal \\
\hline EU493452* & APMV-I/teal/Finland/I2119/06 & Finland & Teal \\
\hline EU493453* & APMV-I/teal/Finland/I2136/06 & Finland & Teal \\
\hline EU493454* & APMV-I/pochard/Finland//3193/06 & Finland & Common pochard \\
\hline
\end{tabular}

* GenBank accession numbers for sequences from isolates obtained in this study

ings have been reported from Denmark in 2003 [40] and Norway in 2005 [41]. As we have not found any methodological reasons to explain the subtype homogeneity of our findings, the results could be explained by the limited time period of sample collection; birds were sampled during one hunting season of only a few months and from a limited number of sampling sites; the material represented only few duck populations (Figure 4). It could also be simply due to the seasonality of subtype prevalences.
All H3N8 isolates, except one from a teal, were derived from mallards.

To conclude, of our 115 swab samples 13 were influenza A RT-PCR positive and of those samples 7 viruses were isolated. In 2006 HPAI H5N1 viruses occurred widely in birds in Europe [38] but were not reported from Finland. Our results, with H3N8 as the only detected subtype, sup-

Table 5: Characterization of avian paramyxovirus-I isolates.

\begin{tabular}{|c|c|c|c|c|}
\hline Isolate & Host & F protein cleavage site & Class $[16,17]$ & Genotype [15] \\
\hline $\mathrm{Fin} / \mathrm{I} 2074 / 06$ & Anas crecca & SGGGKQGRLIG & 2 & I \\
\hline $\mathrm{Fin} / 12104 / 06$ & Anas crecca & SGGERQERLVG & 1 & VI \\
\hline Fin/12119/06 & Anas crecca & SGGERQERLVG & 1 & VI \\
\hline Fin/I2136/06 & Anas crecca & SGGGKQGRLIG & 2 & I \\
\hline $\mathrm{Fin} / 13193 / 06$ & Aythya ferina & SGGERQERLVG & 1 & VI \\
\hline
\end{tabular}

Legend to Table 2: Characterization of the APMV-I isolates. Amino acid sequences at the fusion protein cleavage site (amino acids at position 109-119) and classification of the strains are indicated. 


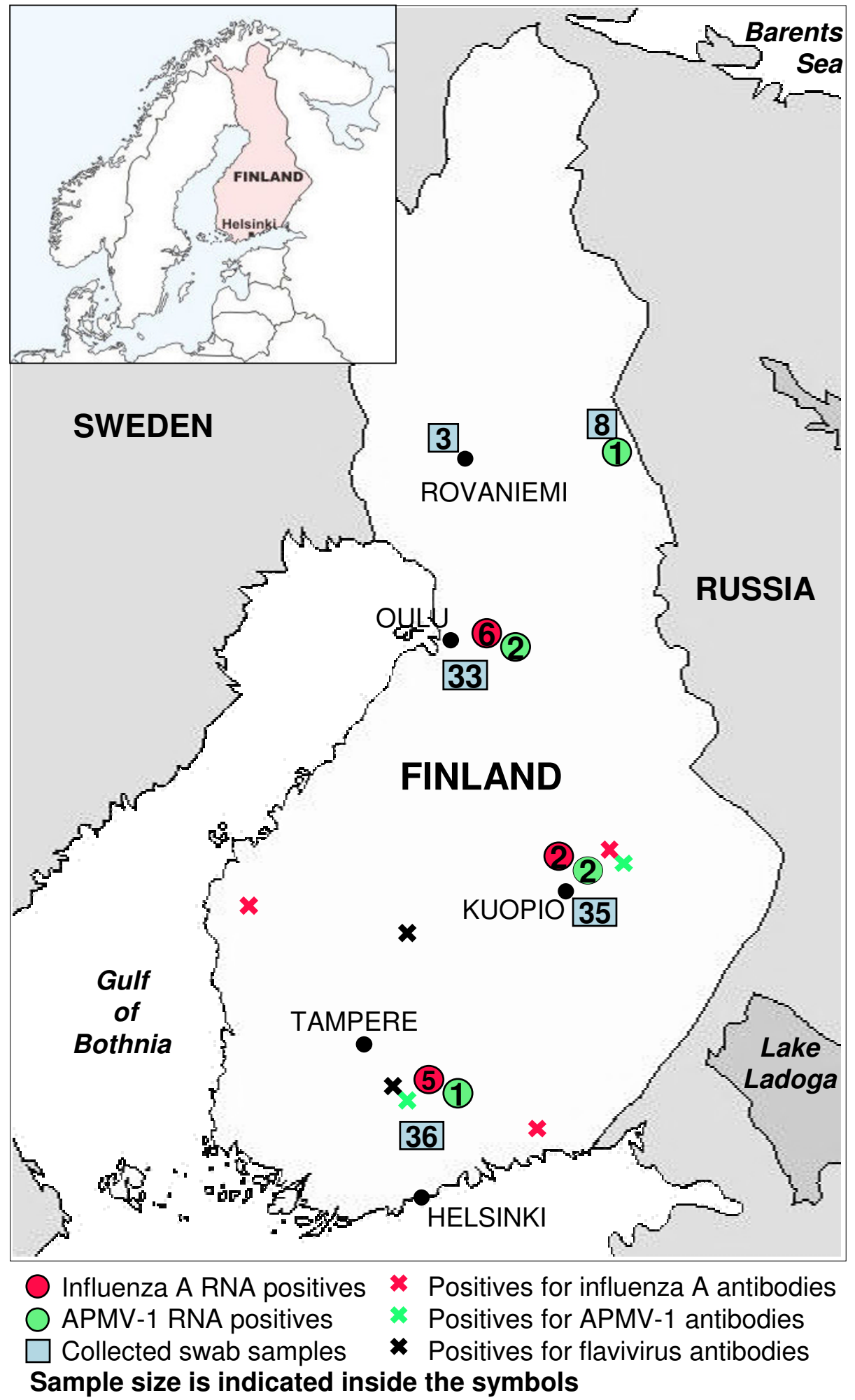

Figure 4

Geographic distribution of collected samples. The squares indicate the total sample size and circles PCR-positive samples. Antibody findings are indicated with a cross. Each virus is marked with its own color. 
port the view that this subtype was indeed absent at that time.

There have been occasional isolations of APMV-1 in Finland from birds representing different orders, e.g. pigeons (Columbidae), pheasants (Phasianidae) and goosander (Mergus merganser). Antigenic and genetic analysis of viruses isolated from three outbreaks in pheasants in Denmark between August and November 1996, from a goosander in Finland in September 1996, from an outbreak in chickens (Gallus gallus) in Norway in February 1997 and from an outbreak in chickens in Sweden 1997 indicate that they were all essentially similar. The results are consistent with the theory that the virus was introduced to the different locations by migratory birds [42]. The latest outbreak in poultry occurred in July 2004 when APMV-1 was isolated from turkeys (Meleagrididae) on a farm in Finland. The pathogenicity index was verified by VLA (Weybridge, UK) to be $>0.7$ and the virus was thereby classified as Newcastle disease virus. The birds were destroyed and the outbreak was handled accordingly. Interestingly, ND was reported from two sites in Sweden at the same time, but no connection to the Finnish outbreak was found. According to VLA reports (Veterinary Laboratories Agency, Weybridge, UK), virus isolates from all three sites were highly similar. The origin of the Finnish outbreak was never found but wild birds were suspected.

The prevalence of APMV-1 was 5.2\% $(n=115)$ in our study. Five of the six RT-PCR positive samples came from common teal, although teals represented only $32.2 \%$ of our material. One isolate derived from the only pochard (Aythya ferina) sampled in this study. Two teals appeared to be infected with both FLUAV and APMV-1.

Based on genetic characterization, our isolates clustered into two distinct lineages (Figure 3). Three isolates (Fin/ 12104/06, Fin/12119/06 and Fin/13193/06) were of class 1 , which represents mainly avirulent viruses found worldwide from wild waterfowl, including the lentogenic strain MC110/77 and velogenic strain 34/90 [12]. The global distribution of the class 1 strains is also seen in the clustering of our isolates with geographically distant isolates. Our isolates were obtained from different sites in North, Central and South Finland, suggesting that viruses of this lineage are dispersed through the country (Figure 4). Interestingly, isolates obtained in a recent North American study [19] of APMV-1 in waterfowl and shorebirds showed high sequence similarity (97-98\%) to our class 1 isolates (data not shown).

Two isolates (Fin/12074/06 and Fin/12136/06) were of class 2, genotype I, which includes Ulster-like viruses. Finnish APMV-1 isolates have been previously character- ized [22], and this is the first time that viruses of genotype I have been found (Figure 3 ). These two isolates were also derived from different regions. Generally viruses of genotype I cause little or no disease in poultry, and derivatives, e.g. Ulster2C/67 and Queensland/V4, have been used as live vaccines in many countries. Avirulent strains have been isolated worldwide in waterfowl but have occasionally been linked to virulent disease outbreaks, e.g. 1998-2000 in Australia [43].

Two basic amino acid pairs surrounding the fusion protein cleavage site usually indicate increased virulence [44]. Analysis of the amino acid sequence of the F-protein cleavage site (109-119) showed all of the isolates to be of avirulent type lacking the basic amino acids (Table 5). Other paramyxovirus types (APMV-2-9) were not studied but these findings show that type 1 avian paramyxovirus is probably endemic in the Finnish waterfowl populations.

None of the samples were positive for Sindbis virus antibodies in the HI test. Previous studies in Finland have demonstrated SINV antibodies in resident grouse (Tetraonidae) with a possibly cyclic pattern. The total prevalence of SINV HI antibodies was $27.4 \%$ in 2003 and dropped down to $1.4 \%$ in 2004 [25]. Wild tetraonid and passerine birds have been suggested to play a role as amplifying hosts and some migratory birds are known to be able to distribute SINV over long distances $[45,46]$. In this study, evidence of the involvement of wild waterfowl in the ecology of SINV was not found.

We found three mallard samples reactive against WNV antigen in $\mathrm{HI}$ test, one of which had a significantly high titer of $1 / 6120$. The lower HI titers towards TBEV are suggestive for antibody specificity against a mosquito-borne flavivirus, however these results require further confirmation by neutralization test [47]. Although previous studies have shown serological evidence of West Nile virus infections in birds in Germany [48], Hungary [49], Poland [50] and the UK [31], to our knowledge, mosquito-borne flavivirus infections have not been reported from Northern Europe. It is possible that migratory birds arriving annually from endemic areas to Finland could carry and transmit mosquito-borne flaviviruses through ornithophilic mosquitoes.

Finally, the involvement of hunters in the sampling of wild waterfowl was found to be a suitable way to screen birds. The percentage of different species in our material (Table 6) correlates well with the percentage of the same species in the nationwide waterfowl bag in 2006 (total bag 552600 individuals) [51]. For example, the four most numerous species in our sample jointly represented $92 \%$ of the birds in the nationwide bag, mallard (51\%) and 
Table 6: Samples and species.

\begin{tabular}{|c|c|c|c|}
\hline Species & & Blood samples (\%) & Swab samples (\%) \\
\hline Mallard & Anas platyrhynchos & $155(50.0)$ & $55(47.8)$ \\
\hline Common teal & Anas crecca & $84(27.1)$ & $37(32.2)$ \\
\hline Eurasian wigeon & Anas penelope & $23(7.4)$ & $6(5.2)$ \\
\hline Common goldeneye & Bucephala clangula & $16(5.2)$ & $7(6.1)$ \\
\hline Greylag goose & Anser anser & II (3.5) & 0 \\
\hline Northern pintail & Anas acuta & $6(1.9)$ & $6(5.2)$ \\
\hline Bean goose & Anser fabalis & $5(1.6)$ & $2(1.7)$ \\
\hline Garganey & Anas querquedula & $4(1.3)$ & 0 \\
\hline Tufted duck & Aythya fuligula & $3(1.0)$ & I (0.9) \\
\hline Red-breasted merganser & Mergus serrator & $2(0.6)$ & 0 \\
\hline Common pochard & Aythya ferina & $\mathrm{I}(0.3)$ & $\mathrm{I}(0.9)$ \\
\hline Total & & 310 & 115 \\
\hline
\end{tabular}

Legend to Table 6: The sample size of blood samples collected on filterpaper strips and combined tracheal and cloacal swabs by bird species.

teal $(21 \%)$ being the most numerous bagged species. Most of the sampled birds had presumably migrated from the east (Russia) as only about 200000 pairs of both mallard and teal are estimated to nest in Finland.

\section{Conclusion}

Circulation of both influenza A virus and APMV-1 in Finnish wild waterfowl was documented in this study with prevalences of $11.3 \%$ and $5.2 \%$, respectively. The subtype $\mathrm{H} 3 \mathrm{~N} 8$ was the only subtype of influenza A detected while the APMV-1 viruses detected represented two distinct genetic groups, class 1 and class 2, genotype 1 . The results suggest that both the sampling and detection methods were effective, and the methods would likely have detected e.g. HPAI H5N1 infections occuring in poultry and wild birds in other European countries in 2006. Screening of antibodies was less efficient in detecting the prevalence of infection. Notably, serological evidence of flavivirus infection in wild waterfowl in Finland was documented.

\section{Methods}

\section{Sample overview}

We tested 310 blood samples and 115 mixed tracheal and cloacal swabs from birds representing 11 different species belonging to the order Anseriformes. Mallards (Anas platyrhynchos) were by number the best-represented species, with $50.0 \%$ of the blood samples and $47.8 \%$ of the swab samples. Teals (Anas crecca) counted for $27.1 \%$ and $32.2 \%$ of the respective sample types (Table 6). The samples were collected by hunters during the annual duck hunting season preceding peak fall migration. All samples were collected during an 8-week time-period starting 20th August 2006. The blood sampling covered the whole country while the swab samples were collected from three main areas (Figure 4).

\section{Sample collection}

Hunters were asked to collect blood samples (preferentially from the heart) from hunted waterfowl on filterpaper strips and to enclose the dried samples individually in airtight plastic bags. Samples were sent to the Department of Virology, University of Helsinki. The hunters were asked to identify the species and mark the location and date of collection for each sample. The samples were diluted immediately upon arrival or stored at $-20^{\circ} \mathrm{C}$. Approximately $1 \mathrm{~cm}^{2}$ of blood-stained filter paper was sliced and blood was eluted in $1 \mathrm{ml}$ of Dulbecco's phosphate buffered saline with $0.2 \%$ bovine albumin serum to a final concentration of approximately $1: 10$ [24,25]. Aliquots were stored at $-20^{\circ} \mathrm{C}$ until tested.

Hunters and staff from the Finnish Game and Fisheries Research Institute (RKTL) collected swab samples using commercial nylon-flocked swabs which were placed in tubes containing $1 \mathrm{ml}$ Universal Transport Medium (Copan Innovation, Brescia, Italy). Samples were kept frozen at $-20^{\circ} \mathrm{C}$ until transferred to the laboratory at The Finnish Food Safety Authority (Evira, Helsinki) where they were stored at $-80^{\circ} \mathrm{C}$ until tested. From each bird, tracheal and cloacal swab samples were taken and placed in the same tube. A corresponding blood sample (collected as described above) was available for each of the 115 mixed swab samples.

\section{Serological examination}

Blood samples were tested for antibodies to influenza A with the commercial FLUAcA competitive ELISA Kit based on the nucleocapsid protein (ID.VET, Montpellier, France). Samples were inactivated for 30 minutes in a $+56^{\circ} \mathrm{C}$ water bath prior to testing. The competition percentages were calculated according to the manufacturer's recommendations by dividing the sample OD measured at $450 \mathrm{~nm}$ with the negative control OD and multiplying 
the sum with 100. Percentages less than or equal to 45 were considered positive, percentages higher than or equal to 50 negative and percentages between 45 and 50 borderline. Samples with a competition percentage less than 55 were re-examined.

Blood samples were examined individually for antibodies to APMV-1, SINV and flaviviruses by hemagglutination inhibition test (HI). Prior to testing, for HI microtitration with SINV and flavivirus antigens, the diluted serum samples were absorbed with kaolin and male goose erythrocytes. For microtitration with APMV-1 antigen the serum samples were inactivated for 30 minutes in $\mathrm{a}+56^{\circ} \mathrm{C}$ water bath.

Blood samples were screened for antibodies by HI test using WNV, SINV and APMV-1/Ulster antigens. As all the viruses in the flavivirus group are cross-reactive in HI, West Nile virus-positive samples were further analysed in a parallel HI test with both WNV and TBEV antigen. The SINV, WNV and TBEV strains used were inactivated with Tween-ether and APMV-1 with formaldehyde. Human seropositive and seronegative sera were used as controls for SINV, WNV and TBEV. For APMV-1 a positive turkey serum was used as control. The HI was performed with two-fold dilutions starting from 1:20. The protocol for the detection of arbovirus antibodies by $\mathrm{HI}$ has been described previously [52-54]. The protocol for the detection of APMV-1 infection was adapted from Council Directive 92/66/EEC Annex III [55], with the exception that rooster erythrocytes were used instead of chicken erythrocytes. The APMV-1 controls and NDV/Ulster antigen were obtained from VLA (Weybridge, UK).

\section{RNA extraction and RT-PCR}

RNA was extracted from swab samples using semi-automated ABI PRISM ${ }^{\mathrm{TM}} 6100$ Nucleic Acid PrepStation and reagents (Applied Biosystems, Foster City, CA, USA). Influenza A viruses were detected by a real time RT-PCR assay targeting the highly conserved matrix gene [56]. Samples with cycle threshold (Ct) values $<40$ were further studied with a real time RT-PCR targeting the H5 and H7 genes [57]. In order to detect as many strains as possible, two different primer pairs were used for APMV nucleic acid amplification by RT-PCR (Table 7), described previously by Seal et al. [58] and Huovilainen et al. [22]. Both primer pairs target the F-gene and include the fusion protein cleavage site.

RNA from 100 swab specimens were also studied by a heminested RT-PCR. The primers are according to and protocol adapted from the method described by Scaramozzino et al. [33] with minor modifications.

\section{Virus isolation and characterization}

All samples positive in the FLUAV matrix gene real-time RT-PCR and in APMV-1 RT-PCR assays were subjected to virus isolation attempts by inoculating swab specimen into the allantoic cavity of four 8-10 day-old embryonated chicken eggs. The allantoic-amniotic fluids were harvested from eggs with dead and dying embryos as they arose and from all remaining eggs six days post-inoculation, and were tested for hemagglutinating activity. FLUAV isolates were tentatively characterized by HI test using subtype-specific polyclonal antisera obtained from VLA.

The preliminary genetic subtyping was done by sequencing the both ends of RT-PCR products of HA and NA genes

Table 7: Primers used for influenza A and avian paramyxovirus-I amplification.

\begin{tabular}{|c|c|c|}
\hline Gene & Forward primer & Reverse primer \\
\hline \multirow[t]{6}{*}{ AIV HA } & hal [59] & h3a \\
\hline & TAT TCG TCT CAG GGA GCA AAA GCA GGG G & TTG TCA AAA TTG TCA TTG TTT GG \\
\hline & h3c & h3b \\
\hline & GCA AAA GGG GAC CTG CTA G & TTC CCA TTG ATC TGG TCA ATG \\
\hline & h3d & ha2 [59] \\
\hline & TCA GGC ATC AAA ATT CCG AAG & ATA TCG TCT CGT ATT AGT AGA AAC AAG GGT GTT TT \\
\hline \multirow[t]{5}{*}{ AIV NA } & nal [59] & n8a \\
\hline & $\begin{array}{l}\text { TAT TGG TCT CAG GGA GCA AAA GCA GGA GT } \\
\mathbf{n} \mathbf{8 b}\end{array}$ & $\begin{array}{l}\text { GGA ATT AAT GAC GTC AGT AGG } \\
\mathbf{n} \mathbf{8 c}\end{array}$ \\
\hline & GCC TGA TTC CAA AGC AGT AG & GTT GGG TAT TTA TGT GCA GGG \\
\hline & n8c & NA2 [59] \\
\hline & GTT GGG TAT TTA TGT GCA GGG & ATA TGG TCT CGT ATT AGT AGA AAC AAG GAG TTT TTT \\
\hline \multirow[t]{4}{*}{ APMV-I F } & Fa [58] & $\mathrm{Fb}[58]$ \\
\hline & CTG CCA CTG CTA GTT GIG ATA ATC C & CCT TGG TGA ITC TAT CCG IAG \\
\hline & Fc [22] & Fd [22] \\
\hline & CCC TCC TTG CCC CGC TC & CTG CTG CAT CTT ACC TAC \\
\hline
\end{tabular}

(I stands for inosine) 
as described by Hoffman et al. [59] and performing BLAST searches with the obtained data. All isolates were serologically and genetically typed as $\mathrm{H} 3 \mathrm{~N} 8$ viruses and the HA and NA genes of A/mallard/Finland/12072/06 were amplified and sequenced with three overlapping primer pairs (Table 7).

APMV-1 strains were amplified and sequenced using the PCR primers targeting the F-gene $[22,58]$. The 208-nucleotide-long sequences covering the fusion protein cleavage site were subjected to phylogenetic analysis and converted to amino acid sequence. The basic amino acids surrounding the fusion protein cleavage site (109-119) were studied as pathogenicity markers (Table 5).

PCR products for sequencing were extracted using Mini Gels, DNA Recovery Kit and BandPick ${ }^{\mathrm{TM}}$ (Elchrom Scientific, Cham, Switzerland). The sequencing reactions were run on Applied Biosystems 3100 Avant capillary DNA sequencer and using BigDye Terminator v3.1 chemistry (Applied Biosystems). Reaction products were purified using DyeEx 2.0 Spin Kit (Qiagen, Helsinki, Finland).

\section{Sequence analysis}

Phylogenetic analysis was performed on the nucleotide sequences of full-length $\mathrm{H} 3$ and $\mathrm{N} 8$ genes. The middle parts of the genes were analysed for all FLUAV isolates but sequence from only one strain (A/mallard/Finland/ 12072/06) was used for phylogenetic analysis as the nucleotide sequence of all strains were highly similar, though not identical. Additionally, phylogenetic analysis on the partial F-gene (nt 4846-5053) of all APMV-1 isolates and the sequence obtained from one APMV-1 RTPCR positive sample, which failed to grow, was included.

The sequences were compared with published sequences by search in EBI WU-Blast2 database [60]. For alignments and phylogenetic trees the most closely related, according to the BLAST-search, and more distant strains were chosen. Nucleotide sequences were managed within the BioEdit [61], and aligned with ClustalX [62]. Phylogenetic trees were generated by the neighbor-joining algorithm within the PHYLIP 3.67 package [63] from 100 or 500 bootstrap replicates. Maximum likelihood (PHYLIP) was used to calculate the branch lengths of the consensus trees, and these were presented graphically by the TreeView program [64].

\section{Competing interests}

The author(s) declare that they have no competing interests.

\section{Authors' contributions}

The study was conceived and the manuscript drafted by $\mathrm{EL}, \mathrm{OV}$ and $\mathrm{AV}$. AH and CE-K additionally contributed to the study design and revision of the manuscript. EL was the main author and performed serological assays, analysis and interpretation of data and sequences, and coordinated sample collection. AH provided expertise in molecular genetics and influenza A and CE-K in serology, virus isolation and in APMV-1. OR and HP coordinated sample collection and provided expertise in avian ecology. TS contributed with expertise in phylogeny and generation of phylogenetic trees and $\mathrm{EH}$ with development of WNV-HI. Along with study design, OV and AV provided expertise in virology and zoonotic diseases. All authors' have read and approved the final manuscript.

\section{Acknowledgements}

We thank all the volunteer hunters who collected the samples for this study, especially Heikki Koivunen (RKTL), Jorma Korhonen (RKTL), Petri Timonen (RKTL), Einari Väyrynen (RKTL), Juha-Pekka Väänänen and VeliMatti Väänänen (University of Helsinki). We would also like to acknowledge Tytti Manni (University of Helsinki) for providing antigens used in this study and Tiina Helkiö (Evira), Leena Kostamovaara (University of Helsinki) and Auli Saarinen (University of Helsinki) for excellent technical assistance. The supplies for swab sample collection were very kindly provided by Copan and Mekalasi. The study was financially supported by TEKES (Finnish National Technology Agency).

\section{References}

I. Webster RG, Bean WJ, Gorman OT, Chambers TM, Kawaoka Y: Evolution and ecology of influenza A viruses. Microbiol Rev 1992, 56:152-179.

2. Fouchier RA, Munster V, Wallensten A, Bestebroer TM, Herfst S, Smith D, Rimmelzwaan GF, Olsen B, Osterhaus AD: Characterization of a novel influenza $A$ virus hemagglutinin subtype (HI6) obtained from black-headed gulls. J Virol 2005, 79:2814-2822.

3. The World Organisation for Animal Health (OIE) [http:// www.oie.int/eng/info ev/en Al avianinfluenza.htm]

4. Olsen B, Munster VJ, Wallensten A, Waldenstrom J, Osterhaus AD, Fouchier RA: Global patterns of influenza $A$ virus in wild birds. Science 2006, 3 I 2:384-388.

5. Fouchier RA, Olsen B, Bestebroer TM, Herfst S, van der Kemp L, Rimmelzwaan GF, Osterhaus AD: Influenza A virus surveillance in wild birds in Northern Europe in 1999 and 2000. Avian Dis 2003, 47:857-860.

6. Wallensten $A$, Munster VJ, Karlsson $M$, Lundkvist A, Brytting $M$, Stervander M, Osterhaus AD, Fouchier RA, Olsen B: High prevalence of influenza $A$ virus in ducks caught during spring migration through Sweden. Vaccine 2006, 24:6734-6735.

7. Estola T, Saikku P, Pirkola M, Hakkinen I, Veijalainen P, Ek-Kommonen $C$ : Occurrence of influenza $A$ viruses and their antibodies in migratory birds in Finland. Nord Vet Med 1980, 32:321-324.

8. Fauquet CM, Mayo MA, Maniloff J, Desselberger U, Ball LA: Virus Taxonomy, Classification and Nomenclature of Viruses. Eighth ICTV Report Elsevier: Academic Press; 2005.

9. Seal BS, King DJ, Sellers HS: The avian response to Newcastle disease virus. Dev Comp Immunol 2000, 24:257-268.

10. Shengqing Y, Kishida N, Ito H, Kida H, Otsuki K, Kawaoka Y, Ito T: Generation of velogenic Newcastle disease viruses from a nonpathogenic waterfowl isolate by passaging in chickens. Virology 2002, 30 I:206-2II.

II. Collins MS, Strong I, Alexander DJ: Pathogenicity and phylogenetic evaluation of the variant Newcastle disease viruses termed "pigeon PMV-I viruses" based on the nucleotide sequence of the fusion protein gene. Arch Virol 1996, 141:635-647.

12. Collins MS, Franklin S, Strong I, Meulmans G, Alexander DJ: Antigenic and phylogenetic studies on a variant Newcastle disease virus using anti-fusionprotein monoclonal antibodies 
and partial sequencing of the fusion protein gene. Avian Pathol 1998, 27:90-96

13. Lomniczi B, Wehmann E, Herczeg J, Ballagi-Pordany A, Kaleta EF, Werner O, Meulemans G, Jorgensen PH, Mante AP, Gielkens AL Capua I, Damoser J: Newcastle disease outbreaks in recent years in Western Europe were caused by an old (VI) and a novel genotype (VII). Arch Virol 1998, I43:49-64.

14. Herczeg J, Wehmann E, Bragg R, Travassos Dias P, Hadjiev G, Werner O, Lomniczi B: Two novel genetic groups (VIlb and VIII) responsible for recent Newcastle disease outbreaks in Southern Africa, one (VIIb) of which reached Southern Europe. Arch Virol 1999, I44:2087-2099.

15. Aldous E, Mynn J, Banks J, Alexander DJ: A molecular epidemiological study of avian paramyxovirus type I (Newcastle disease virus) isolates by phylogenetic analysis of partial nucleotide sequence of the fusion protein gene. Avian Pathol 2003, 32:239-257.

16. Gould A, Hansson E, Selleck K, Kattenbelt J, Mackenzie M, DellaPorta A: Newcastle disease virus fusion and haemagglutininneuraminidase gene motifs as markers for viral lineage. Avian Pathol 2003, 32:36I-373.

17. Czegledi A, Ujvari D, Somogyi E, Wehmann E, Werner O, Lomniczi $B$ : Third genome size category of avian paramyxovirus serotype I (Newcastle disease virus) and evolutionary implications. Virus Res 2006, 120:36-48.

18. Alexander $\mathrm{D}$ : The epidemiology and control of avian influenza and Newcastle disease. J Comp Path 1995, I I 2: 105-126.

19. Seal B, Wise M, Pedersen J, Senne D, Alvarez R, Scott M, King D, Yu $Q$, Kapczynski D: Genomic sequences of low-virulence paramyxovirus-I (Newcastle disease virus) isolates obtained from live-bird markets in North America not related to commonly utilized commercial vaccine strains. Vet Microbiol 2005, 106:7-16.

20. Estola T, Wahlberg C, Berger R: Observations on an enzootic outbreak of Newcastle disease in the Helsinki zoo. Proc. I3th International Symposium on Zoo Animals in Helsinki Academik Verlag, Berlin:277-28I.

21. Estola T: Isolation of a Finnish Newcastle disease virus with an exceptionally high thermostability. Avian Dis 1974, 18:274-277.

22. Huovilainen A, Ek-Kommonen C, Manvell R, Kinnunen L: Phylogenetic analysis of avian paramyxovirus I strains isolated in Finland. Arch Virol 200I, I 46:1775-1785.

23. Kurkela S, Manni T, Myllynen J, Vaheri A, Vapalahti O: Clinical and laboratory manifestations of Sindbis virus infection: Prospective study, Finland, 2002-2003. J Infect Dis 2005 191: | 820-1829.

24. Brummer-Korvenkontio M, Vapalahti O, Kuusisto P, Saikku P, Manni T, Koskela P, Nygren T, Brummer-Korvenkontio H, Vaheri A: Epidemiology of Sindbis virus infections in Finland 198 I-96: Possible factors explaining a peculiar disease pattern. Epidemiol Infect 2002, 1 29:335-345.

25. Kurkela S, Rätti O, Huhtamo E, Uzcátegui NY, Nuorti PJ, Laakkonen J, Manni T, Helle P, Vaheri A, Vapalahti O: Sindbis virus infection in resident birds, migratory birds, and humans, Finland. Emerg Infect Dis 2008, 14(I):4I-47.

26. Kallio-Kokko H, Uzcategui N, Vapalahti O, Vaheri A: Viral zoonoses in Europe. FEMS Microbiol Rev 2005, 29:105I-1077.

27. Savage HM, Ceianu C, Nicolescu G, Karabatsos N, Lanciotti R, Vladimirescu A, Laiv L, Ungureanu A, Romanca C, Tsai TF: Entomologic and avian investigations of an epidemic of West Nile fever in Romania in with serologic and molecular characterization of a virus isolate from mosquitoes. Am J Trop Med Hyg 1999, 61 (4):600-6II.

28. Murgue B, Murri S, Zientara S, Durand B, Durand JP, Zeller H: West Nile outbreak in horses in Southern France, 2000: The return after 35 years. Emerg Infect Dis 200I, 7:692-696.

29. Roehrig JT, Layton M, Smith P, Campbell GL, Nasci R, Lanciotti RS: The emergence of West Nile virus in North America: Ecology, epidemiology, and surveillance. Curr Top Microbiol Immunol 2002, 267:223-240.

30. Komar N: West Nile virus: Epidemiology and ecology in north america. Adv Virus Res 2003, 61: 185-234.

31. Buckley A, Dawson A, Moss SR, Hinsley SA, Bellamy PE, Gould EA Serological evidence of West Nile virus, Usutu virus and Sindbis virus infection of birds in the UK. J Gen Virol 2003, 84:2807-28I7.
32. Waldenstrom J, Lundkvist A, Falk KI, Garpmo U, Bergstrom S, Lindegren G, Sjostedt A, Mejlon H, Fransson T, Haemig PD, Olsen B: Migrating birds and tickborne encephalitis virus. Emerg Infect Dis 2007, 13:1215-1218.

33. Scaramozzino N, Crance JM, Jouan A, DeBriel DA, Stoll F, Garin D: Comparison of flavivirus universal primer pairs and development of a rapid, highly sensitive heminested reverse transcription-PCR assay for detection of flaviviruses targeted to a conserved region of the NS5 gene sequences. J Clin Microbiol 200I, 39: 1922-1927.

34. Nagai $Y$, Klenk HD, Rott R: Proteolytic cleavage of the viral glycoproteins and its significance for the virulence of Newcastle disease virus. Virology 1976, 72:494-508.

35. Collins MS, Bashiruddin JB, Alexander DJ: Deduced amino acid sequences at the fusion protein cleavage site of Newcastle disease viruses showing variation in antigenicity and pathogenicity. Arch Virol 1993, I 28:363-370.

36. Wallensten A, Munster VJ, Latorre-Margalef N, Brytting M, Elmberg J, Fouchier RA, Fransson T, Haemig PD, Karlsson M, Lundkvist A, Osterhaus AD, Stervander M, Waldenstrom J, Bjorn O: Surveillance of influenza A virus in migratory waterfowl in Northern Europe. Emerg Infect Dis 2007, I 3:404-4I I.

37. Kida $\mathrm{H}$, Yanagawa $\mathrm{R}$, Matsuoka $Y$ : Duck influenza lacking evidence of disease signs and immune response. Infect Immun 1980, 30:547-553.

38. Alexander DJ: Summary of avian influenza activity in Europe, Asia, Africa, and Australasia, 2002-2006. Avian Dis 2007, 5I:161-166.

39. Krauss S, Walker D, Pryor SP, Niles L, Chenghong L, Hinshaw VS, Webster RG: Influenza A viruses of migrating wild aquatic birds in North America. Vector Borne Zoonotic Dis 2004, 43:177-189.

40. Bragstad K, Jorgensen PH, Handberg KJ, Mellergaard S, Corbet S, Fomsgaard $A$ : New avian influenza $A$ virus subtype combination H5N7 identified in Danish mallard ducks. Virus Res 2005, 109:181-190

4l. Jonassen CM, Handeland $\mathrm{K}$ : Avian influenza virus screening in wild waterfowl in Norway, 2005. Avian Dis 2007, 5 I:425-428.

42. Alexander DJ, Banks J, Collins MS, Manvell RJ, Frost KM, Speidel EC, Aldous EW: Antigenic and genetic characterization of Newcastle disease viruses isolated from outbreaks in domestic fowl and turkeys in Great Britain during 1997. Vet Rec 1999, | 45:417-42|.

43. Gould AR, Kattenbelt JA, Selleck P, Hansson E, Della-Porta A, Westbury HA: Virulent Newcastle disease in Australia: Molecular epidemiological analysis of viruses isolated prior to and during the outbreaks of 1998-2000. Virus Res 200I, 77:5I-60.

44. Lamb RA, Jardetzky TS: Structural basis of viral invasion: Lessons from paramyxovirus F. Curr Opin Struct Biol 2007, I 7:427-436.

45. Lundstrom JO, Lindstrom KM, Olsen B, Dufva R, Krakower DS: Prevalence of Sindbis virus neutralizing antibodies among Swedish passerines indicates that thrushes are the main amplifying hosts. J Med Entomol 200I, 38:289-297.

46. Sammels LM, Lindsay MD, Poidinger M, Coelen RJ, Mackenzie JS: Geographic distribution and evolution of Sindbis virus in Australia. J Gen Virol 1999, 80:739-748.

47. Calisher CH, Karabatsos N, Dalrymple JM, Shope RE, Porterfield JS, Westaway EG, Brandt WE: Antigenic relationships between flaviviruses as determined by cross-neutralization tests with polyclonal antisera. J Gen Virol 1989, 70:37-43.

48. Linke S, Niedrig M, Kaiser A, Ellerbrok H, Muller K, Muller T, Conraths FJ, Muhle RU, Schmidt D, Koppen U, Bairlein F, Berthold P, Pauli G: Serologic evidence of West Nile virus infections in wild birds captured in Germany. Am J Trop Med Hyg 2007, 77:358-364

49. Glavits R, Ferenczi E, Ivanics E, Bakonyi T, Mato T, Zarka P, Palya V: Co-occurrence of West Nile fever and circovirus infection in a goose flock in Hungary. Avian Pathol 2005, 34:408-4I4.

50. Juricova Z, Pinowski J, Literak I, Hahm KH, Romanowski J: Antibodies to alphavirus, flavivirus, and bunyavirus arboviruses in house sparrows (passer domesticus) and tree sparrows (P. montanus) in Poland. Avian Dis 1998, 42: I82-I85.

51. (Finnish Game and Fisheries Research Institute: Annual Game Bag 2006) Riista-ja kalatalouden tutkimuslaitos, 2007. 
Riistasaaliit 2006. Suomen virallinen tilasto. Maa-, metsä-ja kalatalous. Helsinki. : 32

52. Clarke DH, Casals J: Techniques for hemagglutination and hemagglutination-inhibition with arthropod-borne viruses. Am J Trop Med Hyg 1958, 7:561-573.

53. Vene $S$, Haglund $M$, Vapalahti $O$, Lundkvist $A$ : A rapid fluorescent focus inhibition test for detection of neutralizing antibodies to tick-borne encephalitis virus. J Virol Methods 1998, 73:71-75.

54. Manni T, Kurkela S, Vaheri A, Vapalahti O: Diagnostics of Pogosta disease: Antigenic properties and evaluation of Sindbis virus IgM and IgG enzyme immunoassays. Vector Borne Zoon Dis 2007 in press.

55. Council Directive: Community measures for the control of Newcastle disease. Annex III, 92/66/EEC

56. Spackman E, Senne DA, Myers T], Bulaga LL, Garber LP, Perdue ML Lohman K, Daum LT, Suarez DL: Development of a real-time reverse transcriptase PCR assay for type $A$ influenza virus and the avian $\mathbf{H} \mathbf{5}$ and $\mathbf{H 7}$ hemagglutinin subtypes. J Clin Microbiol 2002, 40:3256-3260.

57. Slomka MJ, Pavlidis T, Banks J, Shell W, McNally A, Essen S, Brown IH: Validated H5 Eurasian real-time reverse transcriptasepolymerase chain reaction and its application in $\mathrm{H} 5 \mathrm{NI}$ outbreaks in 2005-2006. Avian Dis 2007, 51:373-377.

58. Seal BS, King DJ, Bennett JD: Characterization of Newcastle disease virus isolates by reverse transcription PCR coupled to direct nucleotide sequencing and development of sequence database for pathotype prediction and molecular epidemiological analysis. J Clin Microbiol 1995, 33:2624-2630.

59. Hoffmann E, Stech J, Guan Y, Webster RG, Perez DR: Universal primer set for the full-length amplification of all influenza $A$ viruses. Arch Virol 200I, I 46:2275-2289.

60. EMBL-EBI [http://www.ebi.ac.uk/blast2]

61. Hall T: BioEdit. Biological sequence alignment editor for Windows North Carolina State University, NC, USA; 1997.

62. Thompson JD, Gibson TJ, Plewniak F, Jeanmougin F, Higgins DG: The CLUSTAL $X$ windows interface: flexible strategies for multiple sequence alignment aided by quality analysis tools. Nucleic Acids Research 1997, 25:4876-4882.

63. Felsenstein J: PHYLIP (Phylogeny Inference Package), version 3.6 Department of Genome Sciences, University of Washington, Seattle; 2005.

64. Page RDM: TREEVIEW: An application to display phylogenetic trees on personal computers. Computer Applications in the Biosciences 1996, I 2:357-358.

\section{Publish with Bio Med Central and every scientist can read your work free of charge}

"BioMed Central will be the most significant development for disseminating the results of biomedical research in our lifetime. "

Sir Paul Nurse, Cancer Research UK

Your research papers will be:

- available free of charge to the entire biomedical community

- peer reviewed and published immediately upon acceptance

- cited in PubMed and archived on PubMed Central

- yours - you keep the copyright
BioMedcentral 